\title{
Maria s Paradox: Oil Extraction and the Misery of Missing Development Alternatives in the Ecuadorian Amazon
}

Murat Arsel, Lorenzo Pellegrini, and Carlos F. Mena

\section{Introduction}

Maria is a woman in her thirties who lives with her family in a small colono ${ }^{1}$ community in the northern Ecuadorian Amazon ${ }^{2}$. Oil operations are the defining feature of the area: oil pipelines are omnipresent, employees and equipment of the oil company are easy to spot, and oil spills are commonplace. When asked about her perception of the impact of the oil industry, she finds that it has had detrimental effects on the development of her community, environmentally as well as economically, and on the welfare of her own family. Nevertheless, when asked what she thinks about the expansion of oil activities around the community, she responds by expressing her support, explaining that oil companies might provide employment opportunities for her family members. ${ }^{3}$ This chapter investigates the apparent paradox of individuals and communities who are convinced that the overall impact of the oil industry on their welfare is negative but nevertheless agree to the expansion and intensification of oil activities.

This choice is not only surprising given Maria's individual circumstances, which we discuss further later. It also does not fit with existing scholarly approaches, critical or mainstream, depicting the relationship of communities vis-à-vis extractive industries. For instance, Maria and her community, where similar negative views of oil extraction are dominant, are not an example of the myriad of environmental justice struggles of similar communities that bear the burden of extractive activities, benefit very little, and therefore engage in contentious action to resist and obtain redress. While such struggles 


\section{Immiserizing Growth}

have figured prominently in the literature on environmental conflicts and environmental social movements (e.g. Martínez-Alier et al. 2016; Orta Martínez et al. 2018; see also the Environmental Justice Atlas ${ }^{4}$ ), silence and consent in the face of extractive projects have not been equally scrutinized (Akbulut et al. 2017). Maria and her community, as well as many similar individuals and communities encountered in the area, have not taken a 'not in my backyard' (NIMBY) position either. The NIMBY literature focuses on the fact that some individuals and communities are generally in favour of (and might also contribute to) certain economic activities that have negative local impacts, but do not want those impacts when the locality concerned is theirsi.e. their backyard (Heiman 1990). Finally, extractive operations can also be accepted or even welcomed when they are seen as an opportunity by local communities-especially in developing countries-to escape poverty and more generally experience improved economic conditions (cf. Özkaynak et al. 2015; Aragón and Rud 2013). However, Maria's choice does not fit this pattern either since, based on her past experience, she is convinced of the overall negative impact of oil extraction. The argument that we develop in this chapter also challenges the interpretation of Maria's position as a trade-off between economic and other types of welfare and, as explained further in this chapter, the extent of environmental damage produced by the oil industry in the area crowds out opportunities of alternative development, including economic development. What this chapter describes as 'Maria's paradox' can thus be described as an inverse NIMBY syndrome: individuals are cognizant of the negative effects of the oil industry on their welfare and on local development, but express the desire to have more oil extraction in their communities. ${ }^{5}$

In this chapter, we shed light on this paradox by providing an empirically and historically grounded analysis of the rationale underpinning local populations' support for the expansion of oil activities while they express their discontent with respect to their impacts. The overarching framework of our analysis is the immiserizing growth paradigm used to explore the differentiated impacts of the oil industry. The concept of immiserizing growth was introduced in the 1950s to describe the phenomenon of world suppliers of commodities that increase the amounts of export to the global market to such an extent that their terms of trade decline (Bhagwati 1958). Under certain conditions, the decline of terms of trade can be so steep that a growth in exports leads to a contraction of gross domestic product (GDP), the case of 'immiserizing growth'. Our approach differs from this classic formulation, fitting more broadly with Shaffer's (2016) take on the concept as discussed in Chapter 1. We expand the object of analysis to include well-being beyond income. In fact, in this particular case, the immiserization explicitly focuses on well-being broadly understood to include life satisfaction, human health, and the ability to participate in decisions concerning one's environment 
(or environmental citizenship, see Grugel and Singh 2013), including the possibility of realizing strategies for enacting socio-economic development.

The empirical data used in this chapter have been collected during eight years of recurrent research visits in the area. The authors have been engaging in several participatory research projects with communities living in proximity to the oil industry with two main objectives. The first goal is to support local organizations to set up and manage community-based environmental monitoring systems that would enhance the capability to communicate in a timely and actionable manner information regarding liabilities engendered by the oil industry. ${ }^{6}$ The second objective is to use the information collected in the system, in combination with data collected through other research methods, to provide an analysis of the impacts of the oil industry and strategies of resistance towards oil extraction, and to explore the way environmental values are shaped by (and intersect with) identity, class, and gender relations. The research methods include household surveys, participant observation, and focus group discussions. The titular Maria is indeed a real person, though we have used a pseudonym to maintain her privacy and ensure her safety.

In the next section, we briefly discuss the link between immiserizing growth and the environment, discussing our analytical strategy to focus on well-being and its relationship to environmental justice. The third section presents a broader political economy discussion of the historical and structural conditions that shape the contemporary experience of oil extraction in the Ecuadorian Amazon. This narrative is further deepened in section four through an historical overview of how the town of Dayuma and the indigenous community of the Huaoranis have been shaped by their encounter with the oil economy. The penultimate section demonstrates how oil is an overwhelming presence in the Ecuadorian Amazon and how, through its sheer dominance of economic, social, and cultural dynamics, it proscribes the aspiration of any realistic alternatives for local communities to improve their well-being. The brief concluding section problematizes our understanding of Maria's paradoxical support, asking whether it can indeed be seen as a choice since the misery in question emerges from a lack of alternatives.

\section{Immiserizing Growth and the Environment}

As discussed in Chapter 1, and in Shaffer (2016: 1), '[i]mmiserizing growth occurs when economic growth leads to no, or very limited, economic gains for those at the bottom of the distribution'. While economic gains are fundamentally important for the measurement of individual or societal well-being (Arsel and Dasgupta 2015), potential negative impacts of economic growth can certainly spill into social, ecological, and cultural domains-assuming, of 


\section{Immiserizing Growth}

course, that such a separation is tenable. One of the goals of this chapter is to broaden the coverage of the immiserization thesis to capture a wider set of relationships between economic activities and well-being.

This goal stems from the recognition that GDP is an imperfect indicator of human welfare (e.g. Schmelzer 2016). This is not the same as arguing, as it has been by the proponents of a post-development approach, that socioeconomic development is itself the problem (Pieterse 1998). Rather, the argument developed here suggests that efforts to achieve national socio-economic development through extractivism structure local realities and outcomes in such a way that preclude the enactment of development alternatives. ${ }^{7}$ This is especially salient in the study area since a substantial part of the population self-identifies as indigenous, with 32 per cent of Orellana and 13 per cent of Sucumbíos choosing to describe themselves as such in the census survey (INEC 2010). It is important to recognize that the divide between indigenous and colonos is far more fluid than census questionnaires allow, and respondents strategically choose their identity depending on many factors. In any case, the socio-economic and cultural outlook of indigenous Ecuadorians plays an especially strong role in study areas. Since one of the central dimensions of contemporary indigenous political subjectivity has been the questioning of a strictly economistic understanding of development and well-being, equating the absence of growth to misery becomes particularly problematic. Indeed, in the Latin American context, and especially in relation to indigenous cosmologies and understandings of development, a fertile and extensive discussion is taking place on both development alternatives and alternatives to development, stressing factors related to general well-being rooted in different cosmologies that question the link between natural resource extraction and development as well as the isolation of certain aspects of nature as 'natural resources' (Acosta 2010; Gudynas 2016).

To broaden the coverage of the immiserization thesis, we borrow from the environmental justice literature, which has its origins in the attempts of minority communities in the United States to problematize seemingly rational decisions (based, for example, on economistic cost-benefit analysis) to situate environmentally harmful activities (e.g. waste disposal facilities) within or in close proximity to low-income neighbourhoods. The concept of 'environmental justice' is concerned both with the distribution of 'goods' and 'bads' and covers various dimensions of well-being linked to socio-economic development. The following definition demonstrates the potential comprehensiveness of the concept:

Environmental justice is based on the principle that all people have a right to be protected from environmental pollution and to live in and enjoy a clean and healthful environment. Environmental justice is the equal protection and 
Missing Development Alternatives in the Ecuadorian Amazon

meaningful involvement of all people with respect to the development, implementation, and enforcement of environmental laws, regulations, and policies and the equitable distribution of environmental benefits.

(Commonwealth of Massachusetts 2002: 2)

Thus, environmental justice does not focus simply on economic outcomes or even socio-environmental development outcomes as a whole: it also includes the practice of deliberative democracy on environmental decision making and freedom more broadly (Dryzek 2000; Sen 1999; Urkidi and Walter 2011). In our engagements with local communities in the Ecuadorian Amazon, respondents often spoke of tangible ecological liabilities arising from oil extraction and the insidious socio-political dynamics underpinning the dominance of the oil industry in the same breath. More specifically, the disempowering effects associated with information asymmetries, corruption and elite co-optation, and state capture by oil companies are very much part of the negative impacts of oil extraction (cf. Pellegrini and Ribera Arismendi 2012). To this end, it is necessary to broaden the immiserization thesis' coverage from growth to well-being, recognizing the centrality of not only ecological outcomes but also societal processes underpinning environmental degradation. In the following sections, we demonstrate how the putative contribution of extractive activities to economic growth is not only inadequate in and of itself to achieve improved well-being (because of its negative environmental impacts) but also further undermines the possibility of alternative development strategies, thus leading to an immiserizing outcome.

\section{Political Economy of Extraction}

The data analysed in this chapter were collected within a particular conjunction in Latin American development, one in which extractivism has (re-)emerged as a central economic and political strategy (Arsel et al. 2014; Pellegrini 2018). That Latin America has once again placed extractivism at the heart of development processes is rather surprising since the extraction of natural resources for export has a particularly long and dark history in this continent (e.g. Galeano 1973). The myriad tragedies-environmental, social, and economic_-inflicted at the juncture of colonialism and the national extractive processes starting in the fifteenth century have continued to unfold within the context of global capitalism up to the twenty-first century. Yet, extractivism has re-emerged as central to development policy and planning across the region today, to the point that some observers have been talking about a 'commodity consensus' (Svampa 2015). In fact, extractivism is increasingly taking a specific form, which is characterized by the fact that 


\section{Immiserizing Growth}

extraction itself is so central to development that it overrides any other concern; in other words, extractive activities enjoy teleological primacy (Arsel et al. 2016b).

This means that what is observed in Latin America is more than extractivism as an economic policy. To state that it is extractivism taken to an extreme is accurate but not representative of the full story, not even if we describe it as 'neo-extractivism', an approach where extractivism is coupled with public expenditures in social programmes and investment in human and physical capital. Rather, the current shape of extractivist development policy has taken over the logic of all state activities, reorienting policy objectives to further justify and advance the policy of extractivism. It is this broadened, deepened, and self-sustained form of extractivism that can be described as the 'extractive imperative' (Arsel et al. 2016b; Pellegrini 2018; Swallow 2017).

The extractive imperative is grounded on three ideological positions: that intensified extraction is necessary to advance through a Rostowian process of structural transformation; that such a transition away from primary commodity exports to higher value-added (and putatively more sustainable) goods and services (e.g. biotechnology rather than timber, electric cars rather than lithium, etc.) needs to be orchestrated and, to a large extent, executed by the state; and that poverty and inequality need to be addressed aggressively and urgently during this transition and not put aside as ultimate goals of development. As such, the difference between 'extractivism' (or neo-extractivism) and the extractive imperative is more than a semantic one. The former refers to a development model, whereas the latter can be located at a separate ontological plane, as it describes the implications of the development model, including but certainly going beyond state policies, within the current conjuncture.

The confluence of the extractive imperative and rise of leftist governments has resulted in a specific set of state-society relations, marked by the presence of a strong state involved directly in extractive activities, seizing a large share of the rents accruing through extraction. These revenues have been invested in ambitious social policies and infrastructure for economic development, assuring the legitimacy of the state and ensuring continuing popular support of the extractivist drive especially among the urban and peri-urban working classes. Backed by strong electoral majorities, many of these left-turn governments have come to antagonize their early supporters within their countries' rural communities (and progressive non-governmental organizations helping them to defend their interests). As Maria's paradox demonstrates, this process has created outcomes in which immiserization is not strictly an economic dynamic, borne out of market processes and affecting income levels, but one that emerges from societal dynamics and structures, and political choices and outcomes.

In Ecuador, the exploration for petroleum deposits began in the northern part of the Amazon in the 1920s. In 1967 the consortium Texaco-Gulf drilled 
the first productive oil well in Lago Agrio, in the Sucumbíos province. Actual production started in 1972 with much fanfare: the installations were blessed by the bishop of Esmeraldas and the President (and military dictator) Guillermo Rodríguez Lara himself turned the wheel starting the flow of oil. The first barrel of petroleum was carried by tank in a festive procession through the streets of Quito and was finally placed in the temple of heroes of the Military Academy 'Eloy Alfaro'. The national newsreel shot for the occasion claimed that oil extraction was marking 'the beginning of a new era of prosperity', ${ }^{8}$ and in 1973 Ecuador's military regime joined OPEC (the Organization of the Petroleum Exporting Countries). The oil industry became so influential in the recent history of Ecuador that it initiated what has been called the 'petroleum period' that would last one decade and come to an abrupt end with the decline in oil prices in the 1980s (Falconí-Benítez 2001; Sawyer 2004: 11).

Meanwhile, the national economy became emblematic of the 'resource curse': being dependent on the export of a small range of commodities, with oil providing the lion's share of export revenues and financing a large part of the state budget. Oil had also been used as collateral for increasing indebtedness, and the abrupt decline of oil prices in the 1980s gave way to a period of economic instability and a debt crisis. In 1982, President Hurtado launched the first austerity programme-bringing an end to a decade of high growth rates-and announced that 'the age of petroleum prosperity has come to an end.... It is necessary to begin an age of austerity' (Sawyer 2004: 11-12). As early as one decade after the beginning of the commercialization of the 'black gold', the promise of oil-based development had turned into a mirage; the economics and politics of the country would continue to be haunted by the promise of incipient development and the reality of the resource curse (Acosta 2011; cf. Pellegrini 2018).

High oil prices in the first decade of the 2000s have engendered hopes for economic development that in many ways are reminiscent of the hopes dating back from the 1970s. The ascent to power of President Rafael Correa, amid the broader 'left turn' in Latin American, prompted the design and implementation of a developmentalist project that was leveraging the country's natural riches (Arsel et al. 2016a). The nationalization of the oil industry, radical but also rational in a time of high prices (Berrios et al. 2011), substantially increased state revenues that have been used to finance expanded social policies and public investment instrumental to economic development (Arsel et al. 2014). The combination of high oil prices and increased revenues for the state combined to generate what has been defined as a unique window of opportunity to break with (post-)colonial history (Arsel 2012; cf. Pellegrini 2018). With the decline in the second half of 2014 of oil prices, the viability of this project came into question. While it is too early to know whether this is a temporary decline in prices and how the 


\section{Immiserizing Growth}

national economy will respond in the medium to long term, the process of development through extraction is being questioned again, and as of $2017 \mathrm{a}$ new round of austerity measures has been enacted (El Empresario 2017).

The role of oil in the Ecuadorian Amazon, the Oriente, is more pronounced than in the rest of the country, and it is the defining feature of the local economy that otherwise remains mostly rural with low population density. Beyond the direct economic effect related to the creation of employment and service opportunities, there are negative economic externalities that compromise the development of other economic sectors. The subnational Dutch disease effect, due to the increase in prices of non-tradable goods and services relative to the rest of the country, creates a generalized geographical disadvantage for oil-producing regions (cf. Raveh 2013). Moreover, other sectors such as tourism are negatively affected by the presence of oil infrastructure and oil operations that undermine potential eco-tourism destinations.

\section{Extraction, Destruction, Conflict}

The small town of Dayuma in the Orellana Province, located on a stretch of a long road that cuts across Ecuador's oil-producing regions, is an unlikely location to epitomize the paradoxical outcomes produced by the immiserization dynamics of the country's five-decade aspiration to achieve extractive-led development. With its small shops and food stalls lining the main road and its population of 15,000 living in haphazardly constructed housing, it looks like many other towns across rural Ecuador. Nevertheless, the failure of extractivism to deliver a sense of well-being to the local communities have repeatedly come to a head in this otherwise unremarkable town, resulting in conflicts that have at times led to national crises. Dayuma is emblematic because it brings together three interrelated dynamics underlying the immiserization of oil-led growth: the painful encounter between Ecuador's indigenous communities and outside forces intent on 'civilizing' them; the socio-economic impacts of modernizing forces, including the construction of roads and other oil-related infrastructure as well as the accompanying migration from other Ecuadorian provinces; and the localized impacts of oil production which result in environmental degradation and very limited economic opportunities.

The settlement of Dayuma was named after a member of the Huaorani tribe, whose hunter-gatherer way of life was centred in the area, and who was the first to convert to Christianity in the 1950s. The conversion of Dayuma was a turning point since previous attempts by missionaries had been rebuked and several had been killed by the Huaorani. It was Rachel Saint from the infamous Summer Institute of Linguistics (SIL), a Protestant organization from Texas, 
who facilitated the conversion of Dayuma. Learning the Huaorani language from Dayuma, Silver and other SIL missionaries were gradually able to convert most of the tribe, even though a small number continue to live in isolation (Rival 2012). Conversion to Christianity was not, however, the only outcome of this problematic encounter. With the blessing of the Ecuadorian state itself, the missionaries established a Huaorani reserve in the region and began to relocate the indigenous peoples into newly established settlements (Brady 1997). While the ostensible goal was to 'civilize' these communities by moving them into fixed settlements, it has been argued that a more sinister goal was part of the motivation of the missionaries as well as the Ecuadorian state. This goal was to free up oil-rich territory from the Huaorani who had earned a reputation for their dislike of outsiders and their violent response to encroachment into their territories (Kimerling 2012).

The project to 'pacify' the Huaorani (Rival 2012) and the beginning of the commercialization of Ecuador's oil reserves overlapped very conveniently in the late 1960s. The production of oil began the transformation of Ecuador's Amazonian provinces, collectively referred to as the Oriente. The needs of the entry of oil equipment and workers and the transportation of the oil itself kick-started a process of transformation in the Oriente that continues to this day. The cheapest and most convenient way to assure the mobility of productive forces and the resources in and out of the region is by road, something that hardly existed in the region pre-oil. Thus began a process of carving roads through the Amazon, the most significant of which is perhaps Via Auca. Auca was the term used by another Ecuadorian indigenous nation, the Quechuas, to describe the Huaroani and it literally means 'savages'. Via Auca passed through the now pacified Huaorani territories and further intensified the process through which Huaroani were separated from their natural territories and, since much of their cultural and social relationships were themselves built around their relationship to ecology, unleashed a process of cultural erosion and impoverishment (Brady 1997; Pappalardo et al. 2013).

With the road 'opening up' the region, large numbers of internal migrants such as Maria, colloquially but accurately known as colonos, began to arrive in the region to seek employment in the oil sector and to look for opportunities for improved prospects for prosperity through agrarian development. State policies did not encourage migration only for the sake of oil production. Faced with drastic droughts in the country's southern provinces such as Loja and Machala and aiming to add to the economic dynamism of the Oriente, a law was passed where colonos would be given title deeds to up to 50 hectares of land if they successfully cleared at least 50 per cent of their plot. This led to a massive wave of deforestation in the region, further squeezing out the indigenous communities who depended on the forest for hunting as well as cultural reproduction (Mena et al. 2006). 


\section{Immiserizing Growth}

Given the nature of oil work, very few of the original inhabitants ever found sustained employment in the oil sector. Our recent survey results show that only around 13 per cent of indigenous households have at least one member working for an oil company (as opposed to 25.84 per cent in mestizo households). The rest settled into low-productivity agricultural activities supplemented by petty commodity production and the hunting of wild animals, whose numbers have declined significantly due to a complex set of reasons including improvements in technology and free transportation provided by oil companies (Suárez et al. 2013). The sustainability of the 'old way' of securing livelihoods was eradicated further shortly after the intensification of the oil sector's activities in the Oriente. From the 1970s onwards the region began to experience catastrophic pollution, with cascade effects leading to human exposure to hazardous substances. A later law suit launched by the organizations Frente de Defensa de la Amazonia (FDAAmazon Defense Front) and La Unión de Afectados/as por las Operaciones Petroleras de Texaco (UDAPT-Union of People Affected by Texaco) has argued that Texaco, the company that was behind the opening of Via Auca and the main player in the oil industry of the Oriente, had deliberately dumped millions of gallons of toxic oil production by-products into rivers and streams as well as in unlined pits dug specifically as waste disposal sites. By the time the lawsuit was filed, Texaco had merged with Chevron to become ChevronTexaco, who denied the allegations and argued instead that the pollution was caused by the Ecuadorian state-owned oil company Petroecuador, which had taken over the fields in the 1980s (Martínez-Alier 2011; Sawyer 2006). After several years of legal wrangling, during which the case bounced between different courts in the United States, it landed back in Ecuador, and the small court handling it found ChevronTexaco guilty, ordering it to pay US\$9.5 billion in damages. While ChevronTexaco continues to deny responsibility and is unlikely to pay the fine, follow-up cases are still being heard in various courts, including in Canada, with little effect (Perkel 2018). At the same time, ChevronTexaco has been filing punitive counterclaims against the Ecuadorian plaintiff's case, seemingly aiming to warn others against taking it on in the future (Harvard Law Review 2016). What is clearly documented, however, is the fact that the region, including the area around Via Auca, has suffered extensive environmental degradation that has resulted not only in the loss of ecosystem integrity but also widespread damage to human health, as evidenced by highly elevated rates of cancer among the local communities reported by local activists. Unfortunately, their claims have not been taken seriously enough to even warrant a comprehensive epidemiological study in the region. While the type of pollution behind this case is no longer the norm, the environmental performance of the oil sector is far from satisfactory and oil spills in the area 
around Via Auca, coming mainly from breakdowns in the pipeline system, are far from uncommon. ${ }^{9}$

Shortly after the election of Rafael Correa and his Alianza Pais movement in 2007, who had come to power thanks in no small part to the support of environmentalist and indigenous rights organizations (Arsel 2012), some members of the Dayuma community began a peaceful demonstration. This demonstration is remarkable for at least two reasons. First, the Dayuma demonstrators were not in the streets to demand that oil exploration in the area should be stopped, nor were they complaining about the impacts of Via Auca on their lives and livelihoods. Rather, they were protesting because only twenty-three kilometres of a forty-kilometre road paving project had been completed. In other words, they were in the streets for better roads knowing that it was financed by oil revenues. In the days that followed, the second remarkable aspect of the protests revealed themselves. Equating criticisms of his government's performance in the area as a criticism of extractive industries in general, Correa ordered a heavy-handed crackdown on the protesters, charging them under terrorism laws and denouncing environmentalists as 'infantile' (Becker 2011). The backlash from the state went as far as the arrest of the governor of the province of Orellana on terrorism charges, sending a clear message that no protest, however justified, would be allowed to interrupt oil extraction and the flow of revenues associated with it.

Nevertheless, several years later the community staged another uprising. Their demands were not very different from the first. The goal this time was to secure better and wider bridges for the area because existing bridges had led to a number of road accidents. One demonstrator put their demands as follows: '[Our main] demands are the reconstruction of the twenty-seven bridges on Via Auca that have been promised but the national government did not begin the worksites yet'. ${ }^{10}$ The response once again was heavy handed, with unarmed civilians being faced by military forces who dispersed the crowds after a few days of demonstrations.

The community took to the streets once again in October 2017 in what has become the largest and most sustained demonstration concerning the oil sector in the region in many years. While some of the official communiques released by organizations such as CONAIE (Confederation of Indigenous Nationalities of Ecuador) do contain strongly worded denouncements of the oil sector in general, the demonstrations once again have an ambition that might seem counter-intuitive given the history of the region. The protesters are demanding that the company-in this case the Argentinian Construcciones Globales Andinas-fulfil the promise of its original permit where 80 per cent of the workers at the camp would be hired from local communities. Although the state has not followed the military route this time, perhaps partly due to President Lenin Moreno's efforts to distinguish himself from his 


\section{Immiserizing Growth}

predecessor, it is unlikely that the communities will be able to secure most of their demands except for raising awareness of their ongoing plight.

While in various statements CONAIE and CONFENAIE (Confederation of Indigenous Nationalities of the Ecuadorian Amazon) did also bring up the environmental dimension of oil exploration, their demands are remarkably focused on the economic sphere. They state that the demands of the indigenous nationalities, workers, and peasants are 'focused on improving their living conditions, demanding fair and equitable distribution of oil revenues, since so far there has only been a plundering of the oil from their territories, leaving only forty years of broken promises regarding their claims, causing more poverty and proletarization of the countryside'. Before expressing their dismay that authorities from the state have refused to meet with them, they also expressed their demands that 'qualified and non-qualified staff recruitments should be made locally' and supported the 'parish boards in their call for more [financial] resources for bridges, sewers, schools, ambulance, asphalt for roads, etc., for which the bare minimum investment has not been made despite the volume of resources produced by the territory' (CDES 2017). In other words, the demands of these demonstrations are not unlike the position of Maria, where dissatisfaction with the impact of oil companies is parlayed into demands for employment opportunities rather than used as the basis of a movement that opposes oil extraction in toto. In fact, very few Ecuadorian indigenous communities have adopted and maintained such a clear stance. With Cofán communities accepting oil activities in exchange for increased investments in the shape of a Millennium Community in the Dureno settlement, the Sápara are outliers in a landscape where indigenous communities are far more ambivalent about their political stance and show a considerable degree of division among themselves.

The picture that emerges is a clear one. Essentially, from the conversion of the Huaoranis to Christianity to the opening of their territory first to oil exploitation and later to internal migration, the arrival of roads, bridges, and other infrastructure have, in the words of the protesters themselves, created nothing but 'poverty and proletarization' (CDES 2017). This poverty and proletarization is created both through the environmental effects of oil extraction and its secondary economic effects, with which the communities, after four decades of living side by side with oil installations, are intimately familiar. It is worth noting in this context that the type of poverty invoked in such narratives is not absolute economic poverty, as our survey results indicate that households in the area have assets that are comparable to the national average. It is a type of poverty that is consonant with the environmental justice approach, broadly conceived to include the loss of territorial access, which enables the continuity of indigenous cosmologies in a way that communities themselves can articulate, the degradation of the surrounding environment, 
and the political marginalization of being disempowered vis-à-vis the major decisions concerning one's community. This then leads to an important question: why do the residents of Dayuma voice their demands primarily by focusing on joining this seemingly ill-fated enterprise? More dramatically, why do many of them, as is the case with Maria, even demand the expansion of the oil sector?

\section{Misery of Missing Alternatives}

As the preceding sections have shown, since its discovery in the 1960s oil has played an outsized role in Ecuadorian society in general and in the Oriente in particular. It would be churlish to suggest that its impacts have been wholly negative. In fact, as we have argued elsewhere (Arsel et al. 2016a; Pellegrini 2012), natural resource extraction has contributed to the financing of the state budget and programmes that delivered impressive gains in terms of basic, material indicators of development, especially under the 'left-turn' governments. Under the administration of Rafael Correa for instance, massively increased public spending on health, education, and infrastructure construction has translated into dramatic improvements, especially in contrast to previous administrations who had pinned their hopes on the myth that oil wealth would somehow trickle down (Arsel et al. 2016b).

This is not to suggest, however, that oil extraction has delivered its promise of national development. As the account of Dayuma demonstrates, oil has developed just enough gains - twenty-three of forty kilometres of roads promised, bridges that help vehicles pass difficult river crossings but are not wide enough for safe transport, jobs that are created but most of which end up going to those who do not pay the real price of extraction, etc.-to keep the promise of oil-led development alive. In other words, these partial successes have ensured that the 'petroleum period' has never really ended, at least for the residents of the Oriente. If the failure of oil-led development was complete, Maria and others who call for more extraction not less in the face of its negative impacts would likely direct their developmental aspirations to some other economic process, or perhaps embrace a type of 'post-development' thinking that advocates a sharper break with extractive industries in particular and global capitalism in general (Gudynas 2016).

Maria's community is so deeply embedded in the oil sector that to enter it visitors have to pass through a checkpoint manned by private security guards employed by the oil company. On a recent trip, instructed by local informants that the guards took a dim view of university researchers entering the community, the first two authors of the chapter declared their purpose of visit as tourism. Unconvinced by this narrative but not finding sufficient justification 


\section{Immiserizing Growth}

to turn two foreign visitors away, the guard summoned four fully armed soldiers from the Ecuadorian army stationed nearby, who questioned the authors under the pretext that the relative proximity of the community to the Colombian border necessitated additional checks both to prevent criminal activity (mainly the drug trade) and to ensure the safety of visitors themselves against the risk of kidnapping by the guerrilla.

At the heart of the community lies a large oil installation, with vehicles belonging to the private oil company constituting much of the traffic on the dirt roads. Oil men in uniforms (for most of the employees, except for an occasional clerk or cook, are men) can be seen walking within the perimeter of the compound as well as sitting in the lone restaurant in the village. The twenty surveys conducted in this community revealed opinions that did not diverge dramatically from Maria's, though hers stands out, especially in the detailed follow-up interview, in terms of her vehement belief that oil has been a negative force but one that needs to be amplified nevertheless for its employment generation possibility. At another household in very close proximity to a recent oil spill from a burst pipeline, the female respondent expressed her strong dissatisfaction with not only the spill itself but also the meagre response from the company, who had left a large hole in the ground where the spill had occurred and had taken very little remedial action. The main concern of this respondent was the impact of the spill on water quality since her family draws water from a well that is just a few metres away from the spill. Assurance from the oil company that a water sample collected and analysed right after the accident was clean from contaminants does little to boost confidence that the water quality is not compromised. This experience is in keeping with others in the region in terms of company responses to oil spills, which are usually slow, begrudging, and insufficient. As depicted in Figure 9.1, which shows a similar incident recorded in the Palma Roja parish in the Sucumbíos province in 2017, such 'accidents' have the potential to directly affect the health and livelihood outcomes of individuals exposed to them.

Notwithstanding the damage produced by the oil operations, she did not wish the oil company to leave since her husband was one of the lucky few who actually works for the company. It is also worth noting that their house was significantly larger than many others in the community and constructed with cement as opposed to wood, which is the more common material. Ultimately, however, her views echoed Maria's in arguing that in a community that is several hours from the regional capital Lago Agrio, that can be reached by a dirt road, and whose life is dominated by the company, 'what is the point in complaining about the petroleros?'

Beyond the grim spectacle of oil spills, environmental degradation in the region is a far more gradual and often 'invisible' process. Beyond deforestation, loss of biodiversity, visual and noise pollution, and other manifestations of the 


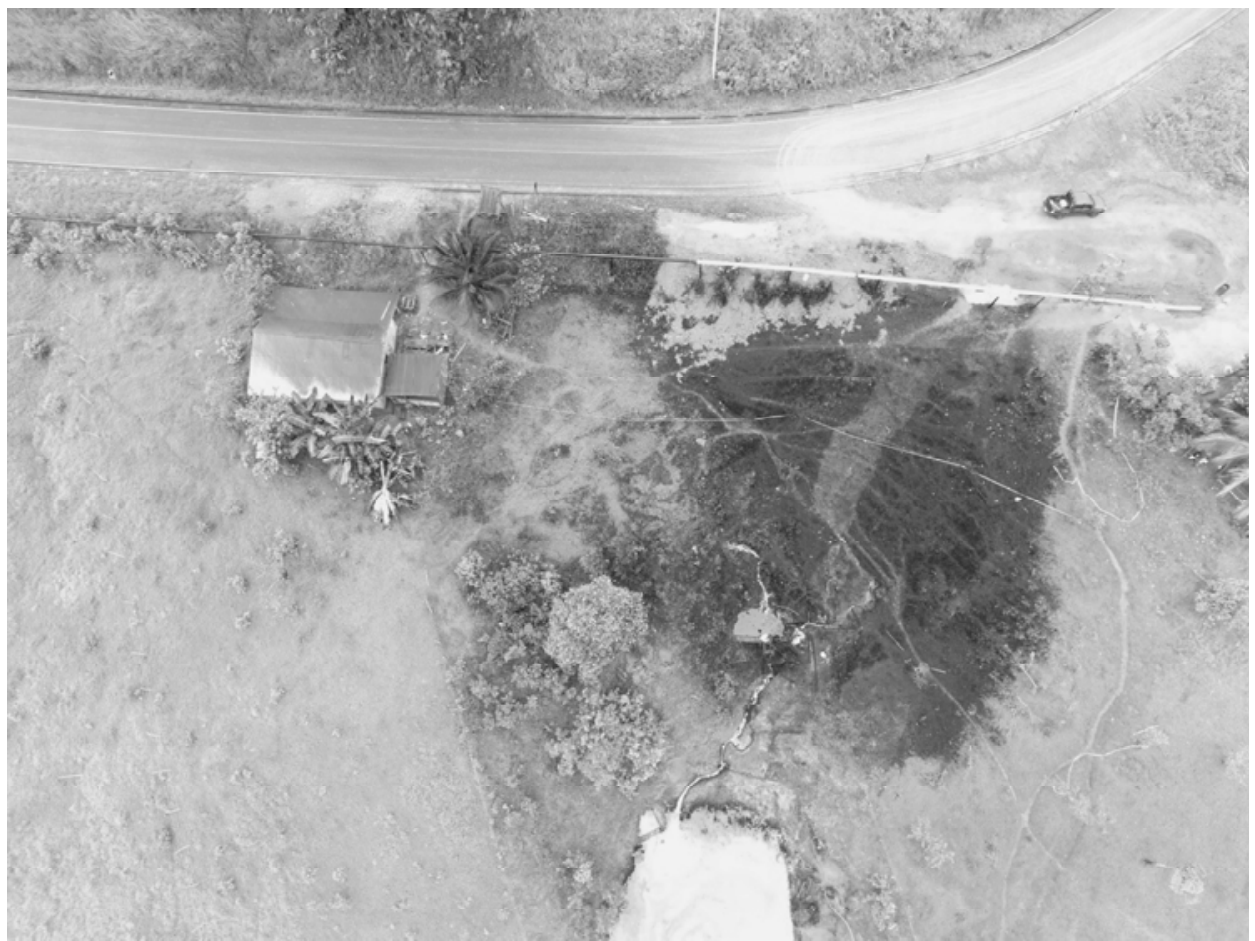

Figure 9.1. Oil spill from a burst pipeline as seen from a drone Photo by UDAPT/FDA community-based monitoring system.

oil-led development, the sector's impacts can be far more insidious and elusive. For instance, emerging research from genetic toxicology has shown that exposure to oil-related contamination in women can have adverse health effects in up to three generations. Beyond the physical domain, the experience of chronic and irreversible environmental degradation can also take a mental toll as well. The type of distress or desolation associated with the chronic environmental degradation of one's home has been called 'solastalgia' (Albrecht 2011: 67-8) and appears to describe aptly the general state of mind of many inhabitants in the area. They observe the steady (and in many cases non-reversible) deterioration of their environments and experience distress, rather that comfort, when thinking about their home. Since the local population has a significant indigenous component, whose identity is linked to the relationship with their ancestral territory, this kind of distress can be particularly acute. Moreover, socially and culturally there are additional adverse effects on local populations: oil operations bring with them social problems associated with drug abuse, prostitution, and criminality (Jochnick 1995; Switkes 1994).

For instance, 'nightclubs' like the one shown in Figure 9.2 are exceedingly common in and near major settlements, such as Lago Agrio, and also smaller oil towns, such as Shushifindi and Pacayacu, and are all too explicit reminders 


\section{Immiserizing Growth}

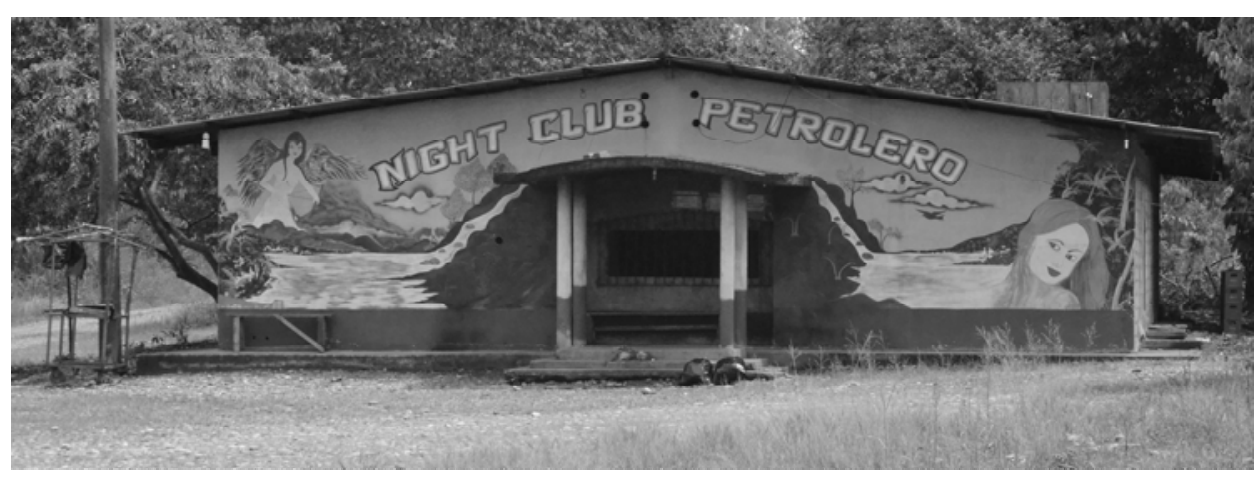

Figure 9.2. 'Nightclub' ‘The Oilman', Pacayacu, Sucumbíos.

Source: Photo by Lorenzo Pellegrini.

that the impact of the oil sector reaches far beyond its environmental and economic impacts. In fact, in a focus group discussion organized by the research team, community representatives argued that conflicts engendered by the extractive industries extend beyond those discussed in relation to Dayuma in the preceding section but enter into the socio-cultural domains as well. Thus, for affected communities rising rates of teenage pregnancies and alcoholism, for example, are direct negative impacts engendered by the oil sector.

Overall, as shown also in our survey results, dissatisfaction with oil is widespread in the region, with the majority believing that its impact has been negative. However, the persistent social, cultural, and environmental degradation and sustained underachievement of oil-led economic development did not translate into the articulation of meaningful alternatives. On the one hand, they have led to paradoxical positions as adapted by Maria as well as the waves of demonstrations in Dayuma. On the other hand, responses have sought to achieve justice and recognition-as in the case against ChevronTexaco (Kimerling 2006)—but have not suggested coherent alternative development strategies. This is in many ways a failure to translate the incipient movement to construct a coherent indigenous-led development vision into an autonomous vision that could challenge the primacy of oil.

The overwhelming centrality of oil is partly responsible for this shortcoming. As demonstrated in Figures 9.3, 9.4, and 9.5, oil has left an indelible mark on the collective consciousness of the region, with buses, restaurants, and hotels all referencing them in relation to the sector. The emerging concept of buen vivir (living well), which sought to create political and intellectual mobilization against extractives-led development on the basis of indigenous values and practices (Walsh 2010), while receiving much public attention, was not translated into clear policy prescriptions, and politicians that embraced the post-extractivist programme, such as the ecological economist Alberto Acosta, fared very poorly in national elections. Ultimately, buen vivir could 


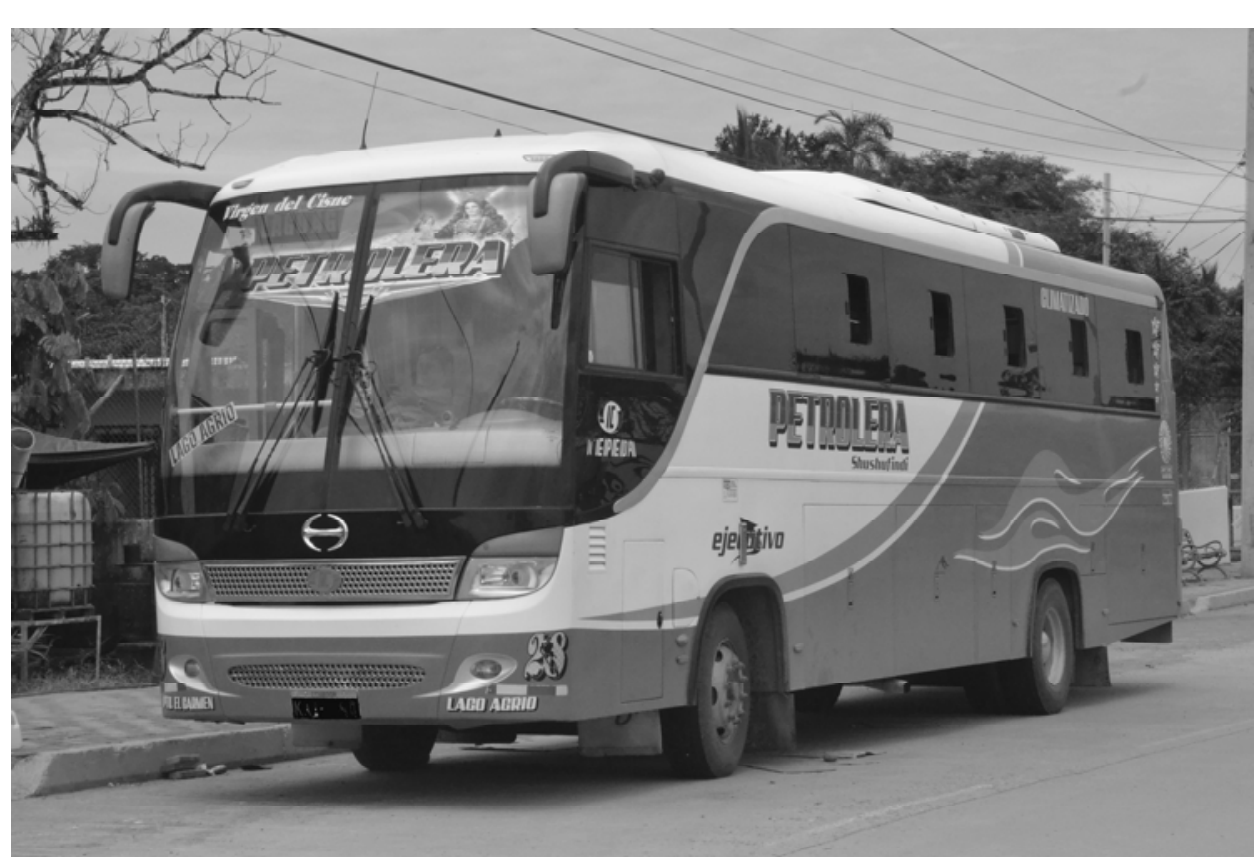

Figure 9.3. The public transport company called 'Oil Company', Tarapoa, Sucumbíos. Source: Photo by Lorenzo Pellegrini.

not challenge the development imaginary-visually or concretely-of the oil sector. Furthermore, the concept was captured by state agencies themselves, portraying the meagre achievements of the extractives-led development model (e.g. construction of 'millennium communities') as examples of how to operationalize buen vivir (Wilson 2017). The clearest example of this is shown in Figure 9.5 in one of the countless billboards placed by the Ecuadorian state along newly built infrastructure projects in the Amazon.

Billboards like this one, telling passers-by that petroleum brings about buen vivir, have not only linked improvement of basic services such as provision of sewage systems to further expansion of the extractive activities in the region. They have also, in a political sleight of hand, redefined what it means to be indigenous, rendering alternative approaches to development synonymous with the achievement of material development objectives that can only be provided by the state through the deepening of extractive practices. Those who disagree with this vision have faced a particularly aggressive state that brooked no opposition to its vision that more extraction, not less, is the answer to Ecuador's developmental woes. The arrest of a provincial governor mentioned in the fourth section is only one example of the increasingly aggressive posture of the state against environmentalists and indigenous communities (Avci and Fernandez-Salvador 2016). In this period, 


\section{Immiserizing Growth}

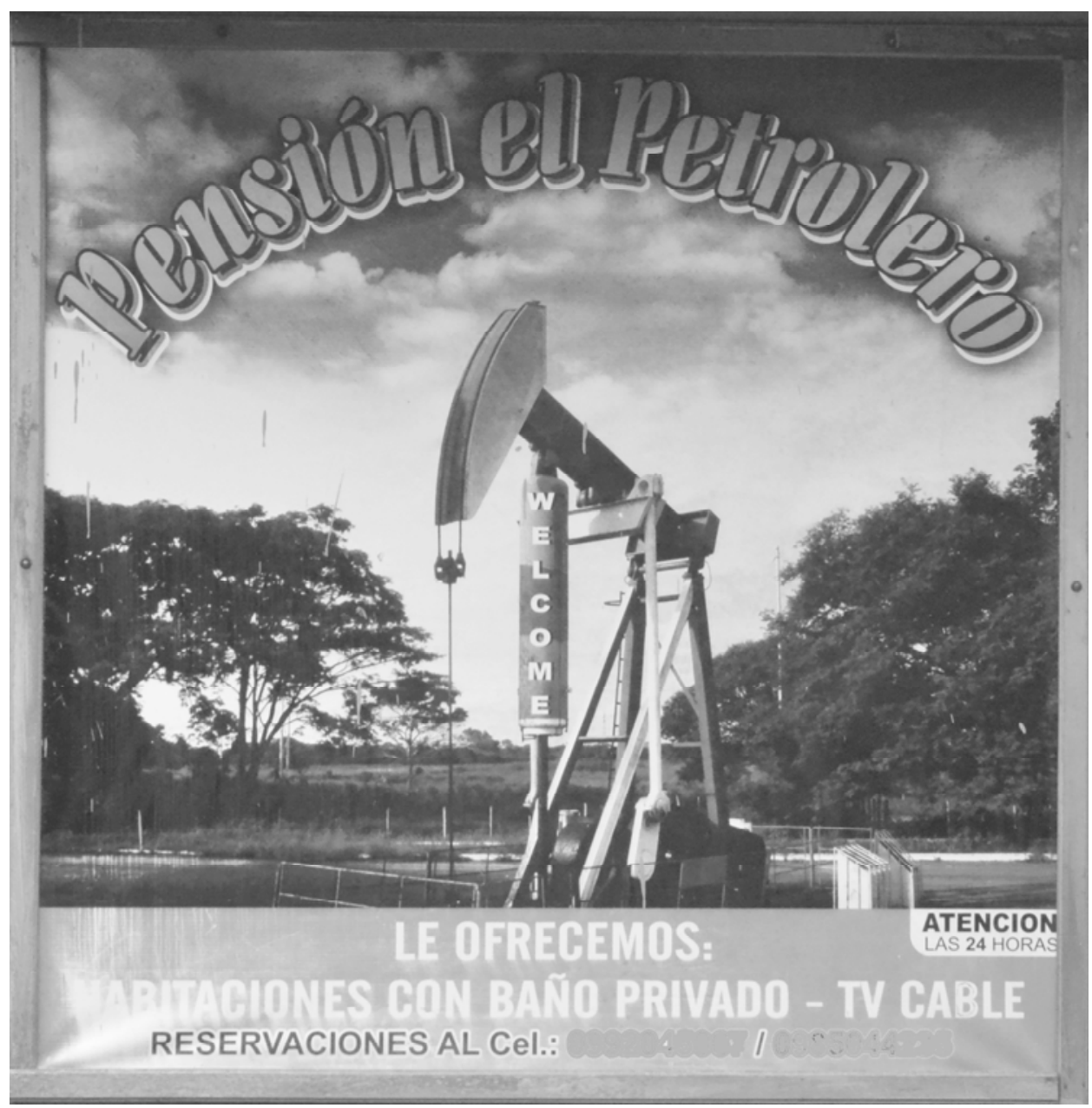

Figure 9.4. Hotel 'The Oilman', Aguas Negras, Sucumbíos. Source: Photo by Lorenzo Pellegrini.

many progressive non-governmental organizations were closed, journalists threatened with newly strengthened libel laws, and critics of the president intimidated via various legal and extra-legal channels. ${ }^{11}$ The result was that alternative demands-those that sought to imagine a development model that did not depend on oil revenues-were not allowed to gain legitimacy. Absent an alternative strategy to deliver material development, the failure of extractivism to deliver all it has promised, as well as the negative outcomes it has engendered, have come to be seen not as the failure of the development model itself but a sign for Maria, therefore, that more oil is needed, not less. Maria's paradox, therefore, is a response to the misery of absent development alternatives. 


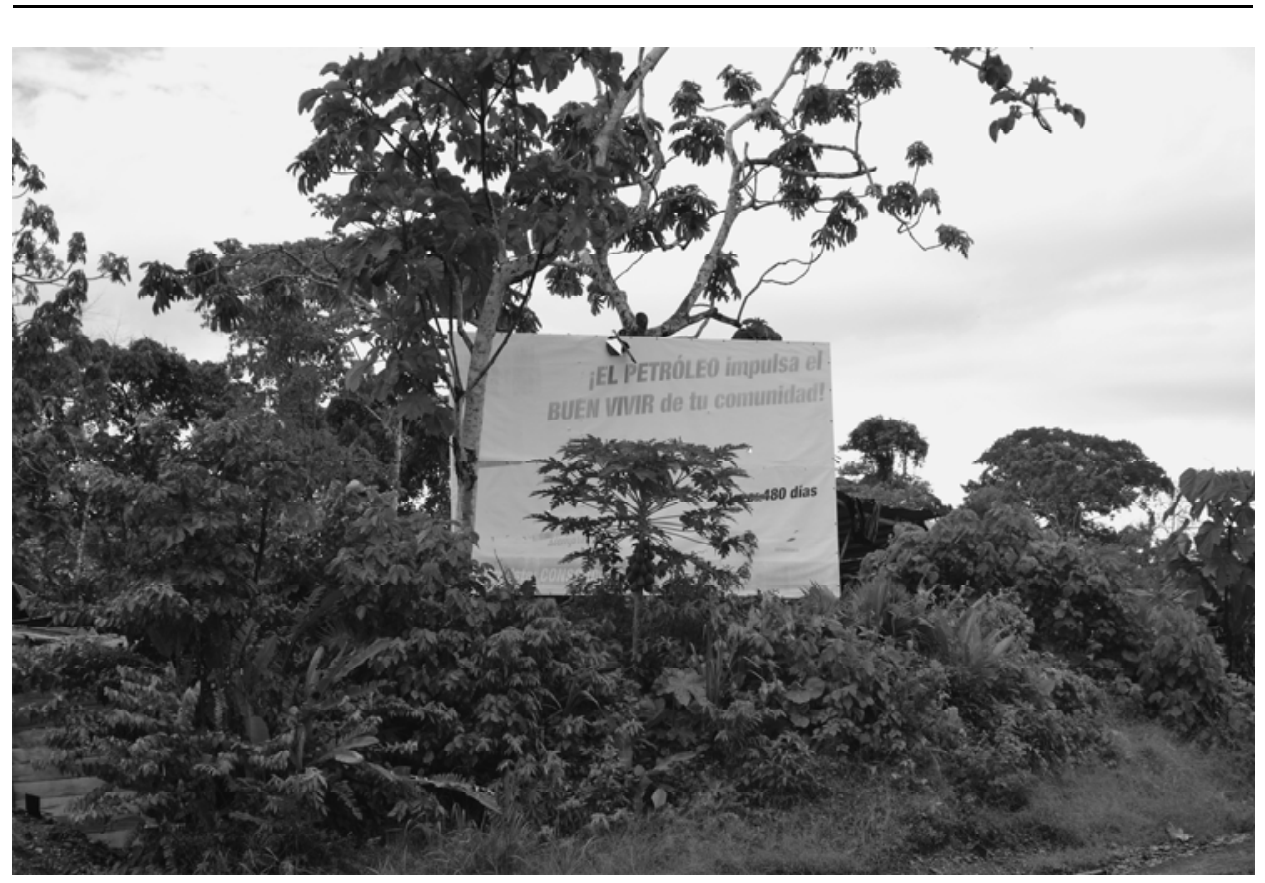

Figure 9.5. One of the numerous billboards placed by the Ecuadorian state. Source: Photo by Lorenzo Pellegrini.

\section{Conclusion}

In seeking to explain Maria's paradoxical views, this chapter opens up a much more complex question regarding the nature of development choices made under conditions of immiserizing growth. Given that the promises of growth have not been-and perhaps cannot be-displaced by alternative visions of well-being, and that the presence of oil creates an 'extractive imperative' that drowns out any other path to development, to what extent can we consider Maria's choice one that is made freely and without compulsion? The significance of this question is amplified by the fact that the limited and partial benefits of oil-led development are in fact the only consolation individuals and communities that live around extractive industries have in the face of steady and extensive deterioration of their natural and social environments. In other words, when the rainforest is cut down, when wild animals are driven away, and when sources of water are contaminated, the only apparent path to the improvement of one's well-being is seen through the construction of roads and bridges that go out of the area and the jobs in extractive industries that provide at least a modicum of stability through their modest wages. Therefore, we argue that the immiserizing effects of oil extraction go beyond their environmental and economic impacts on well-being, but can also be found in the way they crowd out other ways of envisioning and enacting development. 


\section{Immiserizing Growth}

\section{Notes}

1. Colonos in the Ecuadorian Amazon context are the citizens who live in rural areas, but 'originally' come from other areas and do not identify themselves as Indigenous. This definition tends to overlap with the mestizo ethnicity (Castillo and Cairo Carou 2002).

2. The financial contribution of the International Initiative for Impact Evaluation (3ie), Transparency and Accountability in Natural Resources Governance Thematic Window, is gratefully acknowledged.

3. In a household survey $(n=1,200)$ on environmental values and preferences, carried out in October 2017 in the Sucumbíos and Orellana provinces, we found that approximately half of the respondents who were in favour of the expansion of oil activities perceived the overall impacts of the oil industry on the welfare of their families to be negative. The same preferences were expressed (in a less structured way) by several community members and their representatives during individual interviews and focused group discussions.

4. Available at <https://ejatlas.org/>, accessed 16 February 2018.

5. The point is related to, but distinct from, the one made by Gaventa (1982) on the exercise of power to shape consciousness, since we focus on both ideological and material conditions that determine the perceived lack of alternatives.

6. See <http://www.monitoreoparticipativo.org/>, accessed 16 February 2018.

7. In fact, even at the national level and just focusing on GDP, the rich literature on the resource curse suggests that on the average, globally, the extraction of nonrenewable resources is associated with underperformance in terms of economic indicators (van der Ploeg 2011).

8. 'El Primer Barril De Petróleo', <http://www.facebook.com/formacionsocialdelecuador/ videos/345341445636316/>, accessed 20 October 2017.

9. See <http://monitoreoparticipativo.org>, accessed 16 February 2018.

10. Interview with community leader, 19 November 2016, Dayuma.

11. This chapter covers the period coinciding with the exploitation of oil and focuses in particular on the decade coinciding with the 'left turn' in Latin America and the terms of President Rafael Correa, 2007-17, in Ecuador. In May 2017, President Lenín Moreno was sworn in. At the time of writing, while the differences with his predecessor are marked, it is too early to assess the implications of the new path charted by President Moreno.

\section{References}

Acosta, A. (2010). 'El Buen Vivir en el Camino del Post-Desarrollo', Una lectura desde la Constitución de Montecristi, Fundación Friedrich Ebert, FES-ILDIS, Quito.

Acosta, A. (2011). 'Extractivismo y Neo Extractivismo: Dos Caras de la Misma Maldición', ecoportal.net.

Akbulut, B., Adaman, F., and Arsel, M. (2017). 'The Radioactive Inertia: Deciphering Turkey's Anti-nuclear Movement', in F. Adaman, B. Akbulut, and M. Arsel, (eds), 


\section{Missing Development Alternatives in the Ecuadorian Amazon}

Neoliberal Turkey and Its Discontents: Economic Policy and the Environment under Erdogan. London: I.B. Tauris, 175-90.

Albrecht, G. (2011). 'Chronic Environmental Change: Emerging "Psychoterratic" Syndromes', in I. Weissbecker (ed.), Climate Change and Human Well-being. New York: Springer, 43-56.

Aragón, F. M. and Rud, J. P. (2013). 'Natural Resources and Local Communities: Evidence from a Peruvian Gold Mine', American Economic Journal: Economic Policy, 5(2): $1-25$.

Arsel, M. (2012). 'Between Marx and Markets? The State, the "Left Turn" and Nature in Ecuador', Tijdschrift Voor Economische en Sociale Geografie, 103(2): $150-63$.

Arsel, M. and Dasgupta, A. (2015). 'Critique, Rediscovery and Revival in Development Studies', Development and Change, 46: 644-65.

Arsel, M., Hogenboom, B., and Pellegrini, L. (2016a). 'The Extractive Imperative and the Boom in Environmental Conflicts at the End of the Progressive Cycle in Latin America', The Extractive Industries and Society, 3(4): 877-9.

Arsel, M., Hogenboom, B., and Pellegrini, L. (2016b). 'The Extractive Imperative in Latin America', The Extractive Industries and Society, 3(4): 880-7.

Arsel, M., Mena, C., Pellegrini, L. et al. (2014). 'Property Rights, Nationalization and Extractive Industries in Bolivia and Ecuador', in M. Bavinck, E. Mostert, and L. Pellegrini (eds), Conflict on Natural Resources in the Global South: Conceptual Approaches. Boca Raton: CRC Press, 109-28.

Avci, D. and Fernandez-Salvador, C. (2016). 'Territorial Dynamics and Local Resistance: Two Mining Conflicts in Ecuador Compared', The Extractive Industries and Society, 3(4): 912-21.

Becker, M. (2011). 'Correa, Indigenous Movements, and the Writing of a New Constitution in Ecuador', Latin American Perspectives, 38(1): 47-62.

Berrios, R., Marak, A., and Morgenstern, S. (2011). 'Explaining Hydrocarbon Nationalization in Latin America: Economics and Political Ideology', Review of International Political Economy, 18(5): 673-97.

Bhagwati, J. (1958). 'Immiserizing Growth: A Geometrical Note', The Review of Economic Studies, 25(3): 201-5.

Brady, J. E. (1997). 'The Huaorani Tribe of Ecuador: A Study in Self-Determination for Indigenous Peoples', Harvard Human Rights Journal, 10: 291-312.

Castillo, L. C. and Cairo Carou, H. (2002). 'Reinvención de la Identidad Étnica, Nuevas Territorialidades y Redes Globales: el Estado Multiétnico y Pluricultural en Colombia y Ecuador', Revista Sociedad y Economía, 3(October): 55-76.

CDES. (2017). 'Trabajadores Y Nacionalidades Indígenas en Dayuma Intensifican el Paro Ante Falta de Respuestas de Autoridades', <http://cdes.org.ec/web/trabajadores-ynacionalidades-indigenas-en-dayuma-intensifican-el-paro-ante-falta-de-respuestasde-autoridades $/>$, accessed 25 October 2017.

Commonwealth of Massachusetts. (2002). 'Environmental Justice Policy', State House, Boston.

Dryzek, J. S. (2000). Deliberative Democracy and Beyond: Liberals, Critics, Contestations. Oxford: Oxford University Press. 


\section{Immiserizing Growth}

El Empresario. (2017). 'El Gobierno de Ecuador emite un decreto de austeridad', <http:// www.elempresario.com/noticias/internacional/2017/09/07/el_gobierno_ecuador_ emite_decreto_austeridad_51535_1093.html>, accessed 16 February 2018.

Falconí-Benítez, F. (2001). 'Integrated Assessment of the Recent Economic History of Ecuador', Population \& Environment, 22(3): 257-80.

Galeano, E. H. (1973). Open Veins of Latin America: Five Centuries of the Pillage of a Continent. New York and London: Monthly Review Press.

Gaventa, J. (1982). Power and Powerlessness: Quiescence and Rebellion in an Appalachian Valley. Urbana: University of Illinois Press.

Grugel, J. and Singh, J. N. (2013). 'Citizenship, Democratisation and Resource Politics', in J. Nem Singh and F. Bourgouin (eds), Resource Governance and Developmental States in the Global South. London: Palgrave Macmillan, 61-83.

Gudynas, E. (2016). 'Beyond Varieties of Development: Disputes and Alternatives', Third World Quarterly, 37(4): 721-32.

Harvard Law Review. (2016). Foreign Relations Law—Judgement Recognition—Second Circuit Upholds Equitable Relief From A Foreign Judgement Under RICO—Chevron Corp. v. Donziger, Nos. 14-0826(L), 14-0832(C), 2016 WL 4173988 (2d Cir. Aug. 8. 2016).

Heiman, M. (1990). 'From "Not in My Backyard!" to "Not in Anybody's Backyard!"', Journal of the American Planning Association, 56(3): 359-62.

INEC. (2010). 2010 Census, <http://www.ecuadorencifras.gob.ec/estadisticas/>, accessed 16 February 2018.

Jochnick, C. (1995). 'Amazon Oil Offensive', Multinational Monitor, 16(1-2): 12-16.

Kimerling, J. (2006). 'Indigenous Peoples and the Oil Frontier in Amazonia: The Case of Ecuador, Chevron Texaco and Aguinda v. Texaco', Indigenous Law and Politics, 38(3): 413-664.

Kimerling, J. (2012). 'Huaorani Land Rights in Ecuador: Oil, Contact, and Conservation', Environmental Justice, 5(5): 236-51.

Martínez-Alier, J. (2011). El Caso Chevron Texaco en Ecuador: una Muy Buena Sentencia que Podría Ser un Poco Mejor. Quito: ALAI, América Latina en Movimiento.

Martínez-Alier, J., Temper, L., Del Bene, D., et al. (2016). 'Is There a Global Environmental Justice Movement?', The Journal of Peasant Studies, 43(3): 731-55.

Mena, C. F., Bilsborrow, R. E., and McClain, M. E. (2006). 'Socioeconomic Drivers of Deforestation in the Northern Ecuadorian Amazon', Environmental Management, 37(6): 802-15.

Orta Martínez, M., Pellegrini, L., and Arsel, M. (2018). "'The Squeaky Wheel Gets the Grease?" The "Conflict Imperative" and the Slow Fight Against Environmental Injustice in Northern Peruvian Amazon', Ecology and Society, 23(3): 7.

Özkaynak, B., Rodríguez-Labajos, B., Ayd n, C. İ., et al. (2015). 'Towards Environmental Justice Success in Mining Conflicts: An Empirical Investigation', EJOLT Report, 14: 96.

Pappalardo, S. E., De Marchi, M., and Ferrarese, F. (2013). 'Uncontacted Waorani in the Yasuní Biosphere Reserve: Geographical Validation of the Zona Intangible Tagaeri Taromenane (ZITT)', PLoS One, 8(6): e66293.

Pellegrini, L. (2012). 'Planning and Natural Resources in Bolivia: Between Rules Without Participation and Participation Without Rules', Journal of Developing Societies, 28(2): 185-202. 


\section{Missing Development Alternatives in the Ecuadorian Amazon}

Pellegrini, L. (2018). 'Imaginaries of Development through Extraction: The "History of Bolivian Petroleum" and the Present View of the Future', Geoforum, 90: 130-41.

Pellegrini, L. and Ribera Arismendi, M. (2012). 'Consultation, Compensation and Extraction in Bolivia after the "Left Turn": The Case of Oil Exploration in the North of La Paz Department', Journal of Latin American Geography, 11(2): 101-18.

Perkel, C. (2018). 'Ecuador Villagers to Press Ontario's Top Court to Overturn Ruling Denying Award Against Chevron', Globe and Mail, 15 April. <https://www.the globeandmail.com/business/article-ecuador-villagers-to-press-ontarios-top-court-tooverturn-ruling/>.

Pieterse, J. (1998). 'My Paradigm or Yours? Alternative Development, Post-Development, Reflexive Development', Development and Change, 29: 343-73.

Raveh, O. (2013). 'Dutch Disease, Factor Mobility, and the Alberta Effect: The Case of Federations', Canadian Journal of Economics, 46(4): 1317-50.

Rival, L. M. (2012). Trekking Through History: The Huaorani of Amazonian Ecuador. New York: Columbia University Press.

Sawyer, S. (2004). Crude Chronicles: Indigenous Politics, Multinational Oil, and Neoliberalism in Ecuador. Durham, NC: Duke University Press.

Sawyer, S. (2006). 'Disabling Corporate Sovereignty in a Transnational Lawsuit', Political and Legal Anthropology Review, 29: 23-43.

Schmelzer, M. (2016). The Hegemony of Growth: The OECD and the Making of the Economic Growth Paradigm. Cambridge: Cambridge University Press.

Sen, A. (1999). Development as Freedom. Oxford: Oxford University Press.

Shaffer, P. (2016). 'Immiserizing Growth: A Research Agenda', Q-Squared Working Paper No. 66, Trent University, Peterborough, Canada.

Suárez, E., Zapata-Ríos, G., Utreras, V., Strindberg, S., and Vargas, J. (2013). 'Controlling Access to Oil Roads Protects Forest Cover, but Not Wildlife Communities: A Case Study from the Rainforest of Yasuní Biosphere Reserve (Ecuador)', Animal Conservation, 16(3): 265-74.

Svampa, M. (2015). 'Commodities Consensus: Neoextractivism and Enclosure of the Commons in Latin America', South Atlantic Quarterly, 114(1): 65-82.

Swallow, P. S. (2017). 'Ecuador Extractive Imperative and the ITT Initiative', Earth Common Journal, 7(1): 1-20.

Switkes, G. (1994). 'The People vs. Texaco', NACLA Report on the Americas, 28(2): 6-10.

Urkidi, L. and Walter, M. (2011). 'Dimensions of Environmental Justice in Anti-Gold Mining Movements in Latin America', Geoforum, 42(6): 683-95.

van der Ploeg, F. (2011). 'Natural Resources: Curse or Blessing?', Journal of Economic Literature, 49(2): 366-420.

Walsh, C. (2010). 'Development as Buen Vivir: Institutional Arrangements and (De)colonial Entanglements', Development, 53(1): 15-21.

Wilson, J. (2017). 'Perplexing Entanglements with a Post-Neoliberal State', Journal of Latin American Geography, 16(1): 177-94. 